UDC 615.038: 615.252.349.7

https://doi.org/10.24959/ubphj.18.173

G. Kravchenko, Matar Mazen, O. Krasilnikova

National University of Pharmacy

\title{
SCREENING OF BEARBERRY LEAVES EXTRACTS HYPOGLYCEMIC EFFECT AND STUDY OF ACUTE TOXICITY
}

Diabetes mellitus type 2 (DM2) is a global health problem. The plant origin medicinal preparations revealed different mechanisms of antidiabetic action. Despite a wide range of plants that have already been studied, other species are of interest. Particularly, Bearberry (Arctostaphylos uva-ursi) attracted our attention because its leaves are rich with biologically active compounds, but hypoglycemic activity has not been studied yet.

The aim of our experiment was studding acute toxicity and hypoglycemic activity of Bearberry extracts on nondiabetic standard models.

Materials and methods. It was conducted the screening of hypoglycemic effect in healthy rats, oral glucose tolerance test in healthy rats and study of acute toxicity. The object of study were water and alcohol polyphenol extracts of Bearberry leaves (extractor -alcohol $50 \%$ and $90 \%$ ).

Results and discussion. Screening and comparative study shows that the maximal hypoglycemic activity revealed Bearberry leaves alcohol extract (extractor - $50 \%$ ethanol, PE50) in dose $100 \mathrm{mg} / \mathrm{kg}$. The least pronounced effect was observed for the introduction of water extract administration.

Conclusions. The results indicate the practicability of this Bearberry leaves extract further study for renewal the range of medicinal products that revealed hypoglycemic activity.

Key words: Bearberry (Arctostaphylos uva-ursi); acute toxicity; hypoglycemic activity; oral glucose tolerance test

г. Б. Кравченко, Матар Мазен, О. А. Красільнікова

Скринінг гіпоглікемічної активності екстрактів з листя Мучниці звичайної та вивчення гострої токсичності

Цукровий діабет 2 типу (ЦД2) є глобальною проблемою охорони здоров'я. Ефективність лікарських препаратів рослинного походження пояснюється різними механізмами антидіабетичної дії. Незважаючи на широкий спектр рослин, які вже піддавалися вивченню, інтерес представляють і інші види. Зокрема, Мучниця звичайна (Arctostaphylos uva-ursi) привернула нашу увагу, так як її листя багате на біологічно активні сполуки, однак їх гіпоглікемічна активність ще не вивчена.

Мета даного експерименту полягала у вивченні гострої токсичності та гіпоглікемічної активності екстрактів Мучниці звичайної на стандартних моделях у здорових щурів.

Матеріали та методи. Було проведено дослідження гіпоглікемічної активності на здорових щурах, пероральний тест толерантності до глюкози на здорових щурах і дослідження гострої токсичності. Об'єктом дослідження були водний і спиртові поліфенольні екстракти листя мучниці звичайної (екстрагент - етанол 50 \% і 90 \%).

Результати та їх обговорення. Скринінг і порівняльне дослідження показують, що максимальну гіпоглікемічну активність проявив спиртовий екстракт з листя Мучниці звичайної (екстрагент - 50 \% етанолу, РЕ50) в дозі 100 мг/кг. Найменший гіпоглікемічний ефект спостерігався при введенні водного екстракту.

Висновки. Результати показали доцільність подальшого вивчення екстракту листя Мучниці звичайної для оновлення асортименту лікарських препаратів з гіпоглікемічною активністю.

Ключові слова: Толокнянка звичайна (Arctostaphylos иva-ursi); гостра токсичність; гіпоглікемічна активність; пероральний тест толерантності до глюкози

А. Б. Кравченко, Матар Мазен, О. А. Красильникова

Скрининг гипогликемической активности экстрактов из листьев Толокнянки обыкновенной и изучение острой токсичности

Сахарный диабет 2 типа (СД2) является глобальной проблемой здравоохранения. Эффективность лекарственных препаратов растительного происхождения объясняется различными механизмами антидиабетического действия. Несмотря на широкий спектр изученных растений, интерес представляют и другие виды. В частности, Толокнянка обыкновенная (Arctostaphylos uva-ursi) представляет научный интерес, так как ее листья богаты биологически активными соединениями, однако их гипогликемическая активность еще не изучена.

Целью нашего эксперимента было изучение острой токсичности и гипогликемической активности экстрактов Толокнянки обыкновенной на недиабетических стандартных моделях.

Материалы и методы. Было проведено исследование гипогликемической активности на здоровых крысах, пероральный тест толерантности к глюкозе на здоровых крысах и исследование острой токсичности. Объектом исследования были водный и спиртовые полифенольные экстракты листьев Толокнянки обыкновенной (экстрагент - алкоголь $50 \%$ и $90 \%$ ).

Результаты и их обсуждение. Скрининг и сравнительное исследование показывают, что максимальную гипогликемическую активность проявил спиртовый экстракт из листьев Толокнянки обыкновенной (экстрагент - 50 \% этанола, РE50) в дозе 100 мг (кг. Наименьший гипогликемический эффект наблюдался при введении водного экстракта.

Выводы. Результаты показали целесообразность дальнейшего изучения экстракта листьев Толокнянки обыкновенной для пополнения ассортимента лекарственных препаратов с гипогликемической активностью.

Ключевые слова: Толокнянка обыкновенная (Arctostaphylos uva-ursi); острая токсичность; гипогликемическая активность; пероральный тест толерантности к глюкозе 


\section{INTRODUCTION}

Diabetes mellitus type 2 (DM2) is a global health problem. More than 230 million people worldwide are affected, and it is expected to reach 350 million by 2025 [1-2].

For the DM2 pharmacological correction clearly are used hypoglycemic drugs of synthetic origin but the naturally compounds complexes obtained from plants are quite popular. That is because there action involved different mechanisms and allows to prevent complications, which always occurs under the DM2 development [3-4]. Despite a wide range of plants that have already been studied, other species are of interest. In this respect our attention was attracted by Bearberry (Arctostaphylos uva-ursi), which leaves are rich with biologically active compounds and has been used for a long time in medical practice. However, this plant hypoglycemic activity was not studied [5]. For this purpose, we conducted Bearberry leaves extracts hypoglycemic screening in healthy (non-diabetic) rats and under glucose load (glucose tolerant test, GTT).

The aim of our experiment was studding acute toxicity and hypoglycemic activity of Bearberry extracts on non- diabetic standard models.

\section{MATERIALS AND METHODS}

Hypoglycemic study in healthy rats [6]. For screening of hypoglycemic activity were used inbred albino male rats (14 weeks age) weighing 180-200 g. Animals were divided into groups $(n=4)$ depending on the aim of the experiment: 1 - intact control (IC) healthy animals, which were administered physiological solution; 2-4 animals administered water polyphenol extract of Bearberry leaves (PEW) in doses 50, 100, $500 \mathrm{mg} / \mathrm{kg}$; 5-7 animals administered $50 \%$ Bearberry leaves ethanol extract (PE50) 50, 100, $500 \mathrm{mg} / \mathrm{kg}$; 8-10 - animals administered $90 \%$ Bearberry leaves ethanol extract (PE90) 50, 100, $500 \mathrm{mg} / \mathrm{kg}$; 11 - animals administered Arphasetin infusion (AI) in recommended dose recalculated for rats $(18 \mathrm{ml} / \mathrm{kg})$. The test extracts were administered to overnight fasted animals orally with the help of gastric catheter sleeved to syringe. Blood glucose concentration were determined with the help of glucometer "One Touch Select" (LifeScan, USA) at the 0, 2, 4.6 and 8 hours after extracts administration, samples were collected by gingival vein punction [7].

Oral glucose tolerance test (OGTT) in healthy rats [6]. In order to study hypoglycemic activity using the OGTT were used inbred albino male rats (14 weeks age) weighing 180-200 g. Animals were divided into groups $(n=6)$ depending on the aim of the experiment: 1 - intact control (IC) healthy animals, which were administered physiological solution; 2 - animals, which were administered glucose solution in dose $3 \mathrm{~g} / \mathrm{kg}$ body weight per os (glucose load, for other group of animals $30 \mathrm{~min}$ after drug administration); 3 - animals after glucose load and administered PEW; 4 - animals after glucose load and administered PE50; 5 - animals after glucose load and administered PE90; 6 - animals after glucose load adminis- tered AI (18 ml/kg); 7 - animals after glucose load administered metformin $(15 \mathrm{mg} / \mathrm{kg})$. The test extracts were administered to overnight fasted animals orally with the help of gastric catheter sleeved to syringe in dose $100 \mathrm{mg} / \mathrm{kg}$. Blood glucose concentration were determined with the help of glucometer "One Touch Select" (LifeScan, USA) at the $0,15,30.60$ and 120 minutes after glucose load, samples were collected by gingival vein punction [7].

Study of acute toxicity. Acute toxicity of PE50 was determined according to the OECD (Organization for Economic Cooperation and development) No. 423 protocol (Protocol) [8]. In experiment were used female rats weighting 160-180 g, 14 weeks age $(n=3)$. According to the Protocol, study was done in two stages. During first stage, 3 groups of animals were administered 100, 600 and $1000 \mathrm{mg} / \mathrm{kg}$ of PE50 respectively intragastrically and observed for the first $4 \mathrm{~h}$ and $24 \mathrm{~h}$ for signs of toxicity and mortality. For the second stage were selected doses 2000, 3000 and $5000 \mathrm{mg} / \mathrm{kg}$ and 3 groups of rats after single ED50 intragastrically administration were supervised for signs of toxicity and mortality for $72 \mathrm{~h}$.

All animals were kept in standard conditions of the NUPh Central Scientific-Research laboratory 7 days or more prior to allow for acclimatization. Animals were housed in polypropylene cages in groups of 3 animals room at $23 \pm 2{ }^{\circ} \mathrm{C}$ and relative humidity of 50-60\% under $12: 12 \mathrm{~h}$ light:dark cycle. The animals were provided standard diet and water ad libitum. The animal experiments were conducted after obtaining institutional ethics committee clearance, in accordance with the "General Ethical Principles of Animal Experiments" (Ukraine, 2001). Bearberry leaves extracts were obtained at NUPh pharmacognosy department under the prof. Koshoviy O. M. supervision.

The statistical processing of the data was carried out using the STATISTICA program (StatSoftInc., USA, version 6.0).

\section{RESULTS AND DISCUSSION}

The first stage of the experiment was done in order to screening and select the most effective extract and dose in non-diabetic rats for the assessment of hypoglycemic effect. We have found that more pronounced hypoglycemic effect was after 6 hours after treatment agents administration (Table). Nevertheless, it was indicated that studied extracts showed a hypoglycemic activity, its distinctiveness significantly depended on the extractor and dose used. Thus, hypoglycemic effect of PEW was not significant during all the time of observation. The significant decrease in blood glucose level was determined for PE50 in doses $50 \mathrm{mg} / \mathrm{kg}$ ( $8.1 \%$ from the baseline), $100 \mathrm{mg} / \mathrm{kg}$ (14.4\% from baseline) and $500 \mathrm{mg} / \mathrm{kg}$ (7.2 \% from baseline). As for PE90 introduction the maximal decrease in blood glucose content was observed also after $6 \mathrm{~h}$ from the extract administration, but only in the dose $100 \mathrm{mg} / \mathrm{kg}$.

As a reference drug was selected Arphasetin, as, currently in the Ukraine pharmaceutical market, it is the only 


\section{HYPOGLYCEMIC EFFECT OF BEARBERRY LEAVES EXTRACTS ON NORMOGLYCEMIC RATS}

\begin{tabular}{|c|c|c|c|c|c|c|c|}
\hline \multirow{2}{*}{ Group } & \multirow{2}{*}{ Treatment } & \multirow{2}{*}{$\begin{array}{l}\text { Dose (on kg of } \\
\text { body weight) }\end{array}$} & \multicolumn{5}{|c|}{ Blood glucose, $\mathrm{mmol} / \mathrm{l}$} \\
\hline & & & 0 & $2 \mathrm{~h}$ & $4 \mathrm{~h}$ & $6 \mathrm{~h}$ & $8 \mathrm{~h}$ \\
\hline 1 & $\mathrm{NaCl}, 0.9 \%$ & $1 \mathrm{mg}$ & $3.97 \pm 0.23$ & $3.92 \pm 0.22$ & $4.04 \pm 0.26$ & $3.83 \pm 0.18$ & $3.85 \pm 0.09$ \\
\hline 2 & \multirow{3}{*}{ PEW } & 50 & $3.91 \pm 0.18$ & $3.96 \pm 0.23$ & $3.87 \pm 0.22$ & $3.91 \pm 0.21$ & $4.02 \pm 0.14$ \\
\hline 3 & & 100 & $4.04 \pm 0.13$ & $3.95 \pm 0.19$ & $4.01 \pm 0.19$ & $3.89 \pm 0.19$ & $3.87 \pm 0.15$ \\
\hline 4 & & 500 & $3.96 \pm 0.19$ & $3.89 \pm 0.21$ & $3.79 \pm 0.14$ & $3.87 \pm 0.17$ & $3.98 \pm 0.23$ \\
\hline 5 & \multirow{3}{*}{ PE50 } & 50 & $4.05 \pm 0.17$ & $3.93 \pm 0.17$ & $3.81 \pm 0.23$ & $3.74 \pm 0.24^{*}$ & $3.90 \pm 0.21$ \\
\hline 6 & & 100 & $4.01 \pm 0.11$ & $3.88 \pm 0.24$ & $3.61 \pm 0.22^{*}$ & $3.43 \pm 0.17^{*}$ & $3.72 \pm 0.24$ \\
\hline 7 & & 500 & $3.99 \pm 0.24$ & $3.94 \pm 0.16$ & $3.78 \pm 0.19$ & $3.70 \pm 0.21^{*}$ & $3.81 \pm 0.19$ \\
\hline 8 & \multirow{3}{*}{ PE90 } & 50 & $3.93 \pm 0.15$ & $3.84 \pm 0.21$ & $3.72 \pm 0.24$ & $3.65 \pm 0.19$ & $3.84 \pm 0.18$ \\
\hline 9 & & 100 & $3.89 \pm 0.10$ & $3.72 \pm 0.18$ & $3.67 \pm 0.18$ & $3.41 \pm 0.14^{*}$ & $3.69 \pm 0.21$ \\
\hline 10 & & 500 & $4.06 \pm 0.16$ & $3.94 \pm 0.22$ & $3.71 \pm 0.21$ & $3.77 \pm 0.09$ & $3.93 \pm 0.23$ \\
\hline 11 & AI & $18 \mathrm{ml}$ & $4.02 \pm 0.22$ & $3.63 \pm 0.21$ & $3.42 \pm 0.24^{*}$ & $3.33 \pm 0.21^{*}$ & $3.82 \pm 0.14$ \\
\hline
\end{tabular}

Notes: ${ }^{*}-\mathrm{p}<0.05$ - Intact control vs treatment groups.

one plant origin preparation - plant species with antidiabetic activity. In our experiment, we administered to laboratory animals the recommended dose recalculated for rats. The results showed the significant blood glucose rate reduction after $6 \mathrm{~h}$ after AI administration by $18.1 \%$. Thereby in normoglycemic study we have observed that glucose reduction rate was more prominenet at a dose $100 \mathrm{mg} / \mathrm{kg}$ for PE50.

For further hypoglycemic activity study OGTT was carried out. Fig. depicts the result of OGTT in healthy rats after extracts oral administration.

As shown in Fig. the baseline levels of blood glucose did not differ among the groups. It was found that glucose load caused hyperglycemia by $60.3 \%$ after $60 \mathrm{~min}$. The administration of PEW did not have a significant ef- fect on the glycemia dynamics. On the contrary, PE50 administration caused a reliable glycemia after 30 minutes by $18.7 \%$, after 60 min by $26.8 \%$ (Fig.). PE90 reduced glucose level in animals by $41.1 \%$ in $60 \mathrm{~min}$. Along with Arphasetin as reference preparation was used Metformin in dose $15 \mathrm{mg} / \mathrm{kg}$.

As a result, determine the ability of Bearberry leaves extracts to reduce hyperglycemia after glucose load found that PE50 provides a significant reduction in glycaemia by 16.8. Thus, the most promising for further study should consider, therefore, further investigation of antidiabetic properties.

As for acute toxicity study, the obtained results sho wed that rats under administration of the PE50 studydoses the animal death and signs of intoxication were

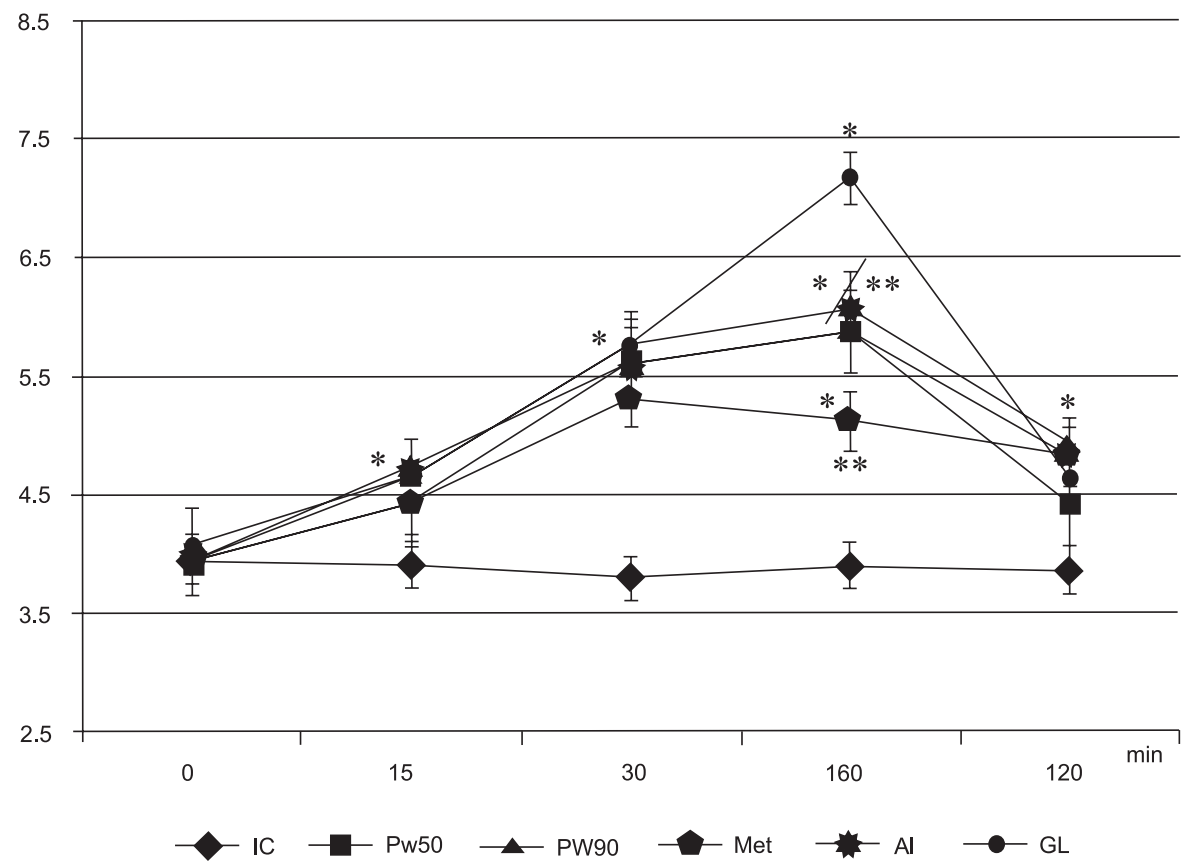

Fig. Effect of Bearberry leaves extracts on blood glucose level ( $\mathrm{mmol} / \mathrm{l})$ in loaded normoglycemic rats Notes: ${ }^{*}-\mathrm{p}<0.05$ - intact control vs treatment groups; ${ }^{* *}-\mathrm{p}<0.05$ - treatment groups vs glucose load 
not observed. Thus, the substance belongs to the class of relatively non-toxic substances with intragastric administration according to the classification of toxicity [6].

\section{CONCLUSIONS}

Screening and comparative study shows that the maximal hypoglycemic activity revealed Bearberry leaves alcohol extract (extractor - 50\% ethanol, PE50) in dose
$100 \mathrm{mg} / \mathrm{kg}$. PE50 belongs to the class of relatively nontoxic substances with intragastric administration.

The results indicate the practicability of this Bearberry leaves extract further study for renewal the range of medicinal products that revealed hypoglycemic activity.

Conflict of Interests: authors have no conflict of interests to declare.

\section{REFERENCES}

1. Dattatreya, A. A Review on Diabetes Mellitus : Complications, Management and Treatment Modalities / A. Dattatreya, T. K. Sarangi // Res. \& Rev J. of Med. and Health Sci. - 2015. - Vol. 4, Issue 3. - 10 p. Available at : http://www.rroij.com/open-access/diabetic-complications-their-treatment.php

2. Clinical Review of Antidiabetic Drugs: Implications for Type 2 Diabetes Mellitus / C. Arun, D. Chitharanjan, S. Vijaya et al. // Frontiers in Endocrinol. - 2017. - Vol. 8, Issue 6. - 12 p. doi: 10.3389/fendo.2017.00006

3. Phytotherapy in the Management of Diabetes: A Review / P. Governa, G. Baini, V. Borgonetti et al. // Molecules. - 2018. - Vol. 23, Issue 1. - 105 p doi: $10.3390 /$ molecules 23010105

4. Antidiabetic plants improving insulin sensitivity / M. Eddouks, A. Bidi, B. El Bouhali et al. // J. of Pharmacy and Pharmacol. - 2014. - Vol. 66, Issue 9. P. 1197-1214. doi: 10.1111/jphp.12243

5. Herbal Medicines for the Management of Diabetic Mellitus in Ethiopia and Eretria including their Phytochemical Constituents / A. Meresa, W. Gemechu, H. Basha et al. // J. of Advanced Drug Delivery. - 2017. - Vol. 05, Issue 01. - P. 40-58. doi: 10.21767/2321-547x.1000011

6. Доклінічні дослідження лікарських засобів : метод. рек. / за редакцією : член-кор. НАМН України О. В. Стефанова. - К. : Авіценна, 2001. - 528 c.

7. de Oliveira, D. T. Gingival Vein Punction : A New Simple Technique for Drug Administration or Blood Sampling in Rats and Mice / D. T. de Oliveira, E. Souza-Silva, T. Scand / J. of Laboratory Animal Sci. - 2009. - Vol. 36, Issue 2. - P. 109-113.

8. Test No. 423 : Acute Oral toxicity - Acute Toxic Class Method / OECD. - 2012. - P. 1-14. doi: 10.1787/9789264071001-en

\section{REFERENCES}

1. Dattatreya, A., Sarangi, T. K. (2015). A Review on Diabetes Mellitus: Complications, Management and Treatment Modalities. Research \& Reviews Journal of Medical and Health Sciences, 4 (3), 10. Available at: http://www.rroij.com/open-access/diabetic-complications--their-treatment.php

2. Chaudhury, A., Duvoor, C., Reddy Dendi, V. S., Kraleti, S., Chada, A., Ravilla, R., Mirza, W. (2017). Clinical Review of Antidiabetic Drugs: Implications for Type 2 Diabetes Mellitus Management. Frontiers in Endocrinology, 8. doi: 10.3389/fendo.2017.00006

3. Governa, P., Baini, G., Borgonetti, V., Cettolin, G., Giachetti, D., Magnano, A., Biagi, M. (2018). Phytotherapy in the Management of Diabetes: A Review. Molecules, 23 (1), 105. doi: 10.3390/molecules23010105

4. Eddouks, M., Bidi, A., El Bouhali, B., Hajji, L., Zeggwagh, N. A. (2014). Antidiabetic plants improving insulin sensitivity. Journal of Pharmacy and Pharmacology, 66 (9), 1197-1214. doi: 10.1111/jphp.12243

5. Meresa, A., Gemechu, W., Basha, H., Fekadu, N., Teka, F., Ashebir, R., Tadele, A. (2017). Herbal Medicines for the Management of Diabetic Mellitus in Ethiopia and Eretria including their Phytochemical Constituents. American Journal of Advanced Drug Delivery, 05 (01). doi: 10.21767/2321-547x.1000011

6. Stefanov, O. V. (2001). Doklinichni doslidzhennia likarskykh zasobiv. Kyiv: Avitsena, 528.

7. de Oliveira, D. T., Souza-Silva, E., Scand, T. (2009). Gingival Vein Punction: A New Simple Technique for Drug Administration or Blood Sampling in Rats and Mice: Journal of Laboratory Animal Science, 36 (2), 109-113.

8. Test No. 423: Acute Oral toxicity - Acute Toxic Class Method. (2012). OECD, 1-14. doi: 10.1787/9789264071001-en

Information about authors:

Kravchenko G., PhD, Associated Professor of the Biological Chemistry department, National University of Pharmacy.

E-mail: annabk2014@gmail.com. ORCID: http://orcid.org/0000-0001-6574-5028

Matar Masen, post-graduate student of the Biological Chemistry department, National University of Pharmacy. E-mail: annabk2014@gmail.com.

ORCID: http://orcid.org/0000-0001-5325-9380

Krasilnikova O., PhD, Associated Professor of the Biological Chemistry department, National University of Pharmacy.

E-mail: krasilnikovaoksana16@gmail.com. ORCID: http://orcid.org/0000-0002-5887-6721

Відомості про авторів:

Кравченко Г. Б., канд. біол. наук, доцент кафедри біологічної хімії, Національний фармацевтичний університет

E-mail: annabk2014@gmail.com. ORCID: http://orcid.org/0000-0001-6574-5028

Матар Мазен, аспірант кафедри біологічної хімії, Національний фармацевтичний університет. E-mail: annabk2014@gmail.com. ORCID: http://orcid.org/0000-0001-5325-9380

Красільнікова О. А., канд. біол. наук, доцент кафедри біологічної хімії, Національний фармацевтичний університет.

E-mail: krasilnikovaoksana16@gmail.com. ORCID: http://orcid.org/0000-0002-5887-6721

Сведения об авторах:

Кравченко А. Б., канд. биол. наук, доцент кафедры биологической химии, Национальный фармацевтический университет.

E-mail: annabk2014@gmail.com. ORCID: http://orcid.org/0000-0001-6574-5028

Матар Мазен, аспирант кафедры биологической химии, Национальный фармацевтический университет. E-mail: annabk2014@gmail.com.

ORCID: http://orcid.org/0000-0001-5325-9380

Красильникова О. А., канд. биол. наук, доцент кафедры биологической химии, Национальный фармацевтический университет.

E-mail: krasilnikovaoksana16@gmail.com. ORCID: http://orcid.org/0000-0002-5887-6721

Рекомендована д. біол. н., професором А. Л. Загайком Надійшла до редакції 18.03.2018 p. 